\title{
Urbanization impact on mosquito community and the transmission potential of filarial infection in central Europe
}

\author{
Viktória Čabanová', Martina Miterpákovál*, Daniela Valentová ${ }^{2}$ Hana Blažejováa ${ }^{3}$ Ivo Rudolf ${ }^{3}$, Eduard Stloukal ${ }^{4}$,
} Zuzana Hurníková ${ }^{1}$ and Marianna Dzidová4

\begin{abstract}
Background: Despite long-term research on dirofilariosis in Slovakia, little attention has thus far been paid to Dirofilaria vectors. The particular aim of the present study was molecular screening for filarioid parasites in two different habitats of Bratislava, the capital city of Slovakia. In addition, the effect of urbanisation on mosquito species abundance and composition, associated with the risk of mosquito-borne infections, was studied and discussed.

Methods: Mosquitoes were identified by morphological features, and molecular methods were also used for determination of selected individuals belonging to cryptic species from the Anopheles maculipennis and Culex pipiens complexes. The presence of filarioid DNA (Dirofilaria repens, Dirofilaria immitis and Setaria spp.) was detected using standard PCR approaches and sequencing.

Results: A total of 6957 female mosquitoes were collected for the study. Overall, the most abundant mosquito species was Aedes vexans, closely followed by unidentified members of the $C x$. pipiens complex and the less numerous but still plentiful Ochlerotatus sticticus species. Further investigation of mosquito material revealed 4. $26 \%$ relative prevalence of Dirofilaria spp., whereby both species, D. repens and D. immitis, were identified. The majority of positive mosquito pools had their origin in a floodplain area on the outskirts of the city, with a relative prevalence of 5.32\%; only two mosquito pools (1.26\%) were shown to be positive in the residential zone of Bratislava. Setaria spp. DNA was not detected in mosquitoes within this study.

Conclusions: The study presented herein represents initial research focused on molecular mosquito screening for filarioid parasites in urban and urban-fringe habitats of Bratislava, Slovakia. Molecular analyses within the Cx. pipiens complex identified two biotypes: Cx. pipiens biotype pipiens and Cx. pipiens biotype molestus. To our knowledge, Dirofilaria spp. were detected for the first time in Slovakia in mosquitoes other than Ae. vexans, i.e. D. repens in Anopheles messeae and unidentified members of An. maculipennis and Cx. pipiens complexes, and D. immitis in Coquillettidia richiardii and Cx. pipiens biotype pipiens. Both dirofilarial species were found in Och. sticticus. The suitable conditions for the vectors' biology would represent the main risk factor for dirofilariosis transmission.
\end{abstract}

Keywords: Dirofilaria, Mosquito-borne diseases, Culex pipiens complex, Anopheles maculipennis complex, Xenomonitoring

\footnotetext{
* Correspondence: miterpak@saske.sk

${ }^{1}$ Institute of Parasitology, Slovak Academy of Sciences, Hlinkova 3, 04001

Košice, Slovakia

Full list of author information is available at the end of the article
}

(c) The Author(s). 2018 Open Access This article is distributed under the terms of the Creative Commons Attribution 4.0 International License (http://creativecommons.org/licenses/by/4.0/), which permits unrestricted use, distribution, and reproduction in any medium, provided you give appropriate credit to the original author(s) and the source, provide a link to the Creative Commons license, and indicate if changes were made. The Creative Commons Public Domain Dedication waiver (http://creativecommons.org/publicdomain/zero/1.0/) applies to the data made available in this article, unless otherwise stated. 


\section{Background}

In recent years, increasing attention has been focused on mosquitoes worldwide due to the growing spread of invasive mosquito species as well as mosquito-borne infectious diseases [1]. Besides viruses, mosquitoes are also responsible for the transmission of medically important protozoans and nematodes, such as the Plasomodium species that causes malaria and several filarioid parasites of human and animals, including Wuchereria bancrofti, Brugia spp. or Dirofilaria spp. [2, 3]. In Europe, dirofilariosis is currently of medical importance. Pets, such as dogs and cats, are the most frequently affected with $D$. repens and $D$. immitis, while human infections are primarily caused by $D$. repens, which is responsible for the subcutaneous and ocular form of the disease [4].

Different mosquito species, mainly of the genera $A e$ des/Ochlerotatus, Anopheles and Culex, are implicated in Dirofilaria spp. transmission [5]. Given the fact that mosquitoes and developing Dirofilaria larvae are strictly dependent on climatic factors, mainly air temperature, the current global environmental change has led to an increase in the spreading of the parasite from endemic areas to previously non-affected regions. Moreover, climate-dependent introduction of invasive mosquito species as well as the spread of exotic mosquitoes (such as Aedes albopictus, Aedes japonicus and Aedes koreicus) through commercial activities are also of a great importance in dirofilariosis (and other mosquito-borne diseases) expansion [2, 6]. At present, the effect of landscape anthropization on mosquito populations is a key factor in the spreading of vector-borne pathogens among both pets and the human communities [7].

Slovakia, located in central Europe, was reported to be endemic for canine dirofilariosis caused by $D$. repens approximately ten years ago [8]. Since then, the detailed results of a comprehensive epidemiological study have been published [9] and several human cases of autochthonous dirofilariosis described [10]. Despite the longterm research, little attention has thus far been paid to Dirofilaria vectors. The first screening for dirofilariosis in mosquitoes was performed in 2013 and showed that the species Aedes vexans was incorporated into both the $D$. repens and the $D$. immitis life-cycles in Slovakia $[11,12]$. However, the mentioned screening was restricted only to several locations in the Košice region, in the south-eastern part of the country. Because most Dirofilaria-infected people in Slovakia come from the south-western part of the country bordering Austria and Hungary, which is also considered endemic area for canine dirofilariosis, we decided to conduct our initial research in this region. The particular aim of the present study was molecular screening for filarioid parasites in mosquitoes collected in two different habitats in Bratislava, the capital city of Slovakia. In addition, the effect of urbanisation on mosquito species abundance and composition associated with the assessment of the risk of mosquito-borne infections was studied and discussed.

\section{Methods \\ Studied localities}

Three localities for mosquito sampling were selected in two different habitats of Bratislava. One of them (Devínske Jazero settlement) was located in an urban-fringe zone, specifically a garden zone, and the other two sampling localities (the Danube riverbank and a dog shelter) were in a residential area in the wider city centre (Fig. 1).

Bratislava is situated in the south-western part of Slovakia at the border with Austria, and it covers an area of $368 \mathrm{~km}^{2}$. The site belongs to the Zahorska Lowland geomorphological unit, which is a part of the Vienna Basin in the Carpathian-Pannonian system. Bratislava is located in an area with the warmest and driest climate in Slovakia. The annual average air temperature in this area reaches $10.3{ }^{\circ} \mathrm{C}$, with $2100 \mathrm{~h}$ of sunlight annually and a mean annual precipitation of $642 \mathrm{~mm}$ [13].

The first studied locality (S1), Devínske Jazero (48 $15^{\prime} 43^{\prime \prime}$ $\left.\mathrm{N}, 48^{\circ} 15^{\prime} 43^{\prime \prime} \mathrm{E}\right)$ is one of the garden zones of Bratislava. This settlement is situated in the Slovak part of the Ramsar Site along the River Morava. Periodic flooding of the Morava creates a floodplain area of size $12 \mathrm{~km}^{2}$. This site is characterised by the largest alluvial meadows of the Cnidion venosi communities in central Europe, a floodplain of softwood forests and eutrophic lakes. The occurrence of many migrating birds in this area contributed to its being designated as an Important Bird Area (IBA). This locality is significantly influenced by the Morava and Danube rivers: the alluvial meadows are flooded in spring and then dry up over the summer [13-15].

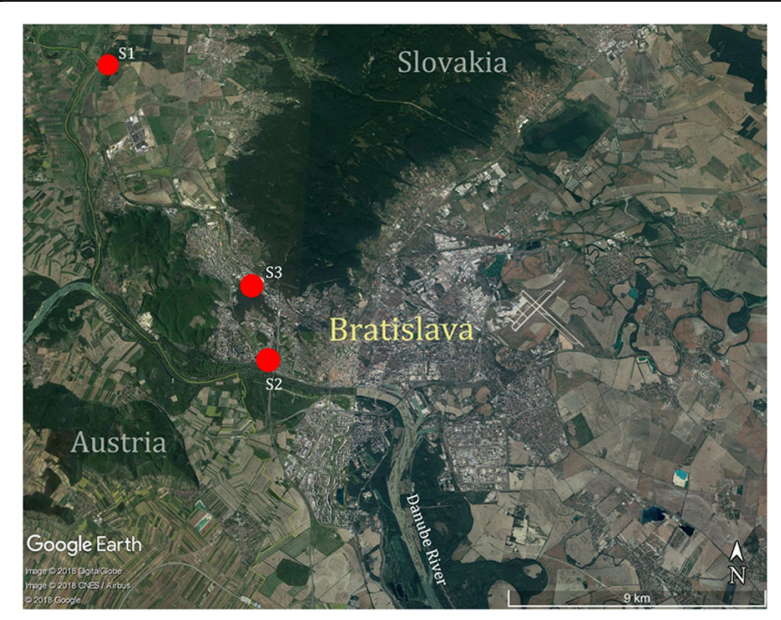

Fig. 1 The sampling sites of mosquitoes in two different habitats of Bratislava. (S1: Devínske Jazero settlement, urban-fringe zone; S2: Danube riverbank, residential zone; S3: dog shelter, residential zone). Source: Google Earth 
The second sampled locality (S2) was situated on the Danube riverbank (100 m from the River Danube itself), directly in a highly urbanised area of the city centre $\left(48^{\circ}\right.$ $\left.08^{\prime} 52.0^{\prime \prime} \mathrm{N}, 17^{\circ} 04^{\prime} 17.5^{\prime \prime} \mathrm{E}\right)$. The promenade located on the Danube riverbank serves as a recreational, sport and walking area for city residents and their pets. A highly visited botanical garden and kayak boathouses are located in the close vicinity. The Karloveské Rameno river branch, one of the few free-flowing river branches in the Slovak section of Danube, adjoins with this sampling area. The vegetation is represented by species characteristic for floodplain forests: Populus nigra (black poplar), Ulmus laevis (European white elm), Fraximus excelsior (European ash), Populus alba (white poplar) and Salix alba (white willow) [16].

The third sampling site (S3) was located in a dog shelter in Bratislava $\left(48^{\circ} 10^{\prime} 25.6^{\prime \prime} \mathrm{N}, 17^{\circ} 03^{\prime} 37.5^{\prime \prime} \mathrm{E}\right)$. The site is situated in the wider city centre, surrounded by a fragment of oak-hornbeam forest in the Líščie údolie valley [13]. The forest connects this area with the neighbouring Bratislava zoological garden, which leads to an assumption of high animal host density. In all, a dozen kennels for several hundred dogs are located here.

\section{Mosquito trapping and identification}

Mosquito collection was performed during three sampling periods conducted between April and October of the years 2015, 2016 and 2017 using BG-Sentinel and BG-Mousquetaire traps (Biogents AG, Regensburg, Germany) enriched with carbon dioxide. The collected mosquitoes were stored at $-20{ }^{\circ} \mathrm{C}$ until their identification. The species richness in the urban-fringe and residential zone was quantified by Menhinick's diversity index (D) which is the ratio of the number of taxa to the square root of sample size $(D=s / \sqrt{ } N)$ where "s" equals the number of different species represented in the sample, and " $\mathrm{N}$ " equals the total number of individual organisms in the sample.

Female mosquito individuals were identified by morphological features under a Leica M125 stereomicroscope (Leica Microsystems GmbH, Wetzlar, Germany) according to the identification key by Becker et al. [2]. Collected females were pooled pursuant to sampling site, trapping date and species from a minimum of one to a maximum of 25 individuals per pool and were stored at $-20{ }^{\circ} \mathrm{C}$. In addition, molecular methods were used for determination of damaged material and selected individuals belonging to cryptic species from the Anopheles maculipennis and Culex pipiens complexes.

Individuals selected for molecular determination were placed into $2 \mathrm{ml}$ Eppendorf tubes with 80-100 $\mu \mathrm{l}$ PBS and a $5 \mathrm{~mm}$ stainless steel bead (Qiagen, Hilden, Germany) and homogenized in Qiagen TissueLyser (Qiagen) at $30 \mathrm{~Hz} / 6$ min. After homogenization, the samples were incubated with $30 \mu \mathrm{l}$ proteinase $\mathrm{K}$ and $180 \mu \mathrm{l}$ ATL buffer at 56 ${ }^{\circ} \mathrm{C}$ for $3 \mathrm{~h}$. Subsequently, DNA was isolated using the DNeasy Blood \& Tissue Kit (Qiagen) following steps in the protocol.

In cases when materials were damaged during trapping, the positive mosquito individuals and pools were verified to the species level by standard polymerase chain reaction (PCR). Fragments of the cytochrome $c$ oxidase subunit 1 ( $\operatorname{cox} 1)$ gene were amplified using primers MTRN/MTFN designed by Kumar et al. [17]. PCR was carried out under the following thermal conditions: $94{ }^{\circ} \mathrm{C}$ for $2 \mathrm{~min}$, followed by 35 cycles at $94{ }^{\circ} \mathrm{C}$ for $30 \mathrm{~s}, 57{ }^{\circ} \mathrm{C}$ for $30 \mathrm{~s}, 72{ }^{\circ} \mathrm{C}$ for $30 \mathrm{~s}$ and a final extension at $72{ }^{\circ} \mathrm{C}$ for $7 \mathrm{~min}$. PCR amplicons were sequenced in both directions by Sanger sequencing. The newly generated sequences were compared with entries available in the GenBank database.

Individuals of morphologically identical members of the Culex pipiens complex (18 females) were selected to be identified by two multiplex PCR assays. First, the variations of the nuclear locus in the acetylcholinesterase-2 gene (ace2) were examined to differentiate $C x$. pipiens biotypes from Culex torrentium. The primer set ACEpall/ACEpip/ACEtorr/B1246s targeting a 416 bp portion fragment in $C x$. torrentium, a 478 bp fragment in $C x$. pipiens pallens and a $610 \mathrm{bp}$ fragment in $C x$. pipiens; forms were used as previously described by Smith \& Fonseca [18] and Zittra et al. [19]. Afterwards, microsatellites of the locus CQ11 were targeted using primers CQ11F/pipCQ11R/molCQ11R according to Bahnck \& Fonseca [20] for identification of the $C x$. pipiens biotypes and their hybrids. Product sizes of 180 bp for $C x$. pipiens biotype pipiens and 240 bp for Cx. pipiens biotype molestus were expected.

In addition, 117 females from the Anopheles maculipennis group were identified by multiplex PCR assay, as described previously by Blažejová et al. [21]. Speciesspecific primers were used to mark the internal transcribed spacer 2 (ITS2) rRNA regions for members of An. maculipennis (s.l.), An. atroparvus, An. sacharovi, An. melanoon, An. labranchiae, An. daciae and An. messeae, as designed by Kronefeld et al. [22]. PCR products were visualised by electrophoresis on $1.5 \%$ agarose gels. Selected amplicons were purified and sequenced (as is described below).

\section{Molecular screening for filarioid species}

For DNA extraction, mosquitoes were divided into pools. To each mosquito pool 180-800 $\mu$ l PBS (according to the number of mosquitoes in pool) and a $5 \mathrm{~mm}$ stainless bead (Qiagen) were added. Samples were homogenized in Qiagen TissueLyser (Qiagen) at $30 \mathrm{~Hz} / 6 \mathrm{~min}$. After homogenization, $50 \mu \mathrm{l}$ proteinase $\mathrm{K}$ was added to each sample and left to incubate at $56{ }^{\circ} \mathrm{C}$ for 24 hours. DNA extraction was provided 
by DNeasy Blood \& Tissue (Qiagen ${ }^{\bullet}$, Hilden, Germany), according to the manufacturer's protocol.

The presence of filarioid DNA was detected by standard PCR. Owing to the expectation of a low concentration of parasite DNA, each sample was re-amplified. In each run, a positive sample (DNA isolated from filarioid worm) and a negative control (nuclease-free water) were used. Every single step, including mosquito identification, DNA extraction, master-mix preparation and gel electrophoresis, was performed in a separate place to prevent sample contamination. For the first screening, universal nematode primers COIintF/COIintR, targeting an approximately $650 \mathrm{bp}$ long fragment of the filarioid cox1 gene, was used [23]. Positive pools were subsequently examined by species-specific primers for $D$. repens (DR COI-F1/DR COI-R1) and D. immitis (DI COI-F1/DI COI-R1) targeting a fragment of the cox1 gene, as designed by Rishniw et al. [24], and primer sets StCol $616 \mathrm{~L} / \mathrm{StCol1105 \textrm {L }}$ to mark a $730 \mathrm{bp}$ region of the cox1 gene and StND4L/StCol747H targeting an $860 \mathrm{bp}$ long fragment of the cox 1 and nad4 genes of members belonging to the genus Setaria [25].

Furthermore, the selected amplicons were purified using NucleoSpin ${ }^{\circ}$ Gel and the PCR Clean-up kit (Macherey-Nagel GmbH \& Co. KG, Düren, Germany) and commercially sequenced in both directions by Sanger sequencing. The Fasta format of sequences were manually edited in MEGA 7 and compared by BLAST with sequences available in GenBank. The respective sequences are deposited in the GenBank database.

\section{Results}

\section{Mosquito species composition and abundance}

A total of 6957 female mosquitoes were collected for this study during the sampling period. Different mosquito species (Aedes vexans, Anopheles hyrcanus, Anopheles plumbeus, Coquillettidia richiardii, Culex modestus, Culiseta annulata, Ochlerotatus caspius and Ochlerotatus sticticus) , two groups of morphologically cryptic species (Anopheles maculipennis complex and Culex pipiens complex) and individuals of Aedes cinereus/geminus that cannot be identified according their morphological features were trapped (Table 1). Some specimens $(n=970)$ were damaged during the sampling process, and their morphological identification was possible only to the genus level (Aedes spp., Anopheles spp. and Culex spp.). Overall, the most abundant mosquito species was Ae. vexans with $38.7 \%$ of the total catch, closely followed by unidentified members of the Cx. pipiens complex (36.5\% of the total catch) and the less numerous, but still plentiful Ochlerotatus sticticus species $(6.0 \%$ of the total catch). Great differences were observed between mosquito abundances in the two monitored habitats of the city. Most of the studied mosquitoes, as many as 6279 , were trapped in the urban-fringe zone
Table 1 Mosquito species/complexes collected in an urbanfringe zone (sampling site S1) and a residential zone (sampling localities S2 and S3) of Bratislava, Slovakia. The most abundant species are highlighted in bold

\begin{tabular}{|c|c|c|c|}
\hline \multirow[t]{2}{*}{ Species/complex } & \multicolumn{3}{|c|}{ Number of mosquitoes } \\
\hline & $\begin{array}{l}\text { Urban-fringe } \\
\text { zone (S1) }\end{array}$ & $\begin{array}{l}\text { Residential zone } \\
(\mathrm{S} 2+\mathrm{S} 3)\end{array}$ & Total \\
\hline Aedes cinereus/geminus & 4 & 1 & 5 \\
\hline Aedes vexans & 2661 & 29 & 2690 \\
\hline Aedes spp. & 764 & 2 & 766 \\
\hline Anopheles hyrcanus & 1 & - & 1 \\
\hline $\begin{array}{l}\text { Anopheles maculipennis } \\
\text { complex }\end{array}$ & 126 & 10 & 136 \\
\hline Anopheles messeae & 56 & na & 56 \\
\hline Anopheles daciae & 61 & na & 61 \\
\hline Anopheles plumbeus & - & 13 & 13 \\
\hline Anopheles spp. & 1 & - & 1 \\
\hline Coquillettidia richiardii & 15 & 33 & 48 \\
\hline Culex modestus & - & 2 & 2 \\
\hline Culex pipiens complex & 2005 & 534 & 2539 \\
\hline Cx. pipiens biotype pipiens & 2 & 11 & 13 \\
\hline Cx. pipiens biotype molestus & - & 5 & 5 \\
\hline Culex spp. & 192 & 10 & 202 \\
\hline Culiseta annulata & 1 & - & 1 \\
\hline Ochlerotatus caspius & 3 & - & 3 \\
\hline Ochlerotatus sticticus & 387 & 27 & 414 \\
\hline Ochlerotatus spp. & - & 1 & 1 \\
\hline Total & $6279(\mathrm{D}=0.19)$ & $678(\mathrm{D}=0.50)$ & 6957 \\
\hline
\end{tabular}

(sampling site S1), while in the urban area (residential zone), only 678 specimens were collected during the entire sampling period. Also, more mosquito taxa were captured in the urban-fringe area; for instance, An. hyrcanus, Cs. annulata and Och. caspius were collected only at the Devínske Jazero sampling site (S1), though only in a few isolated cases. In contrast, An. plumbeus and $C x$. modestus species were observed only in the residential zone of the city. However, using Menhinick's diversity index the calculated mosquito richness was higher in the sampling sites of a residential zone (Table 1).

The designated material from the cryptic groups were analysed based on PCR assays and sequencing. The assay, which targets the locus for ace2, discriminated only Culex pipiens biotypes. Culex torrentium was not detected in our study. From the examined mosquitoes $(n=18), 13$ individuals were identified as the $C x$. pipiens biotype pipiens and 5 mosquitoes as the $C x$. pipiens biotype molestus. A multiplex PCR for species-specific determination of members of the An. maculipennis complex $(n=117)$ 
revealed two species, An. daciae $(n=56)$ and $A n$. messeae $(n=61)$ (Table 1).

\section{Detection of filarioid nematodes}

Four hundred and fifty-one mosquito pools from the urban-fringe zone and 159 pools from the residential zone were processed for molecular screening for filarioid nematodes. Altogether, fragments of filarioids cox 1 gene were detected in 26 pools (4.26\%). Consequential analyses showed $D$. repens was identified as the predominant filarioid species: it was detected in 22 samples (3. $61 \%)$. In contrast, mono-infection of $D$. immitis was detected in only two pools $(0.33 \%)$, and in two samples a mixed infection of $D$. repens and $D$. immitis was confirmed (0.33\%). DNA of Setaria species was not detected in any of the pools examined.

Most of the positive mosquito pools $(n=24)$ had their origin in the floodplain area situated on the outskirts of the city, in the Devínske Jazero settlement, with a relative prevalence of $5.32 \%$. Dirofilaria repens $(n=22)$ was found predominately in this area, but a single case of $D$. immitis and one mixed infection were also detected here. In comparison, only two mosquito pools were shown to be positive in the residential zone of Bratislava (1.26\%): in one of them only D. immitis DNA was confirmed, and in the second both $D$. immitis and $D$. repens were detected (Table 2).

Regarding vector species, $D$. repens was identified primarily in Ae. vexans (9 pools positive) and unidentified members of the Culex pipiens complex (7 pools positive). In addition, 4 pools of $A n$. messeae and 2 pools of the unidentified An. maculipennis complex were positive for D. repens. Dirofilaria immitis DNA was detected only in $C q$. richiardii and the $C x$. pipiens biotype pipiens. One pool of Ae. vexans and one of Och. sticticus were shown to be positive for both $D$. repens and D. immitis (Table 3).

Of the selected cox 1 locus, a 111 bp long overlapped fragment of $D$. repens isolated from Ae. vexans and a 211 bp long fragment of D. immitis isolated from Och. sticticus revealed $100 \%$ similarity with the sequences obtained from Slovak dogs (KC985239 and KC985240, respectively). Both nucleotide sequences of $D$. repens and D. immitis cox 1 gene were deposited in the GenBank database under the accession numbers MG787424 and MG787425.

\section{Discussion}

Currently, mosquitoes are at the centre of medical and veterinary research because of their importance as vectors of a wide range of viral and parasitic infections [2, 26-28]. In Slovakia, concern over mosquitoes has risen during the last decade. Still, research in this field is very rare, and published data are both very limited and sporadic. Moreover, the results of numerous studies have confirmed the emergence of mosquito-borne infections as becoming especially associated with urban environments and anthropization [7, 29]. Therefore, our study presents an initial survey focused on species composition and the abundance of mosquitoes inhabiting Bratislava, as well as the first molecular screening for mosquito-transmitted filarioid nematodes in Slovakia. The studied area is unique from several points of view. Bratislava is the only capital city which neighbours directly with two other countries, Austria and Hungary, and considering flight activity of some mosquito species, this fact puts a transboundary output of our study $[2,13]$. Regarding habitat and ecological conditions, Bratislava is located in a very warm and dry area which favours incubation and development of Dirofilaria in mosquitoes [6]. In addition, the city is located along both sides of River Danube and several times in the past; the rising river has caused extensive floods directly in the city centre, followed by mosquito outbreaks [30, 31].

Almost 7000 mosquitoes were collected during the study, and the mosquito species recorded here are commonly widespread in central Europe. Together, 12 different mosquito taxa (Ae. vexans, An. hyrcanus, An. messeae, An. daciae, An. plumbeus, Cq. richiardii, Cx. modestus, $C x$. pipiens biotype pipiens, $C x$. pipiens biotype molestus, Cs. annulata, Och. caspius and Och. sticticus) were distinguished, in addition to unidentified individuals of $A e$. cinereus/geminus. Our sampling sites were selected in two different habitats: a highly urbanized residential area of the wider city centre (S2 + S3) and an urban-fringe habitat represented by a garden zone of the city (S1). The type of habitat and its individual conditions influenced the

Table 2 Dirofilaria species detected in mosquitoes collected from different urban habitats of Bratislava, Slovakia

\begin{tabular}{llll}
\hline Dirofilaria spp. & \multicolumn{2}{l}{ Number of positive mosquito pools for Dirofilaria spp. (\%) } \\
\cline { 2 - 4 } & $\begin{array}{l}\text { Urban-fringe zone }(\mathrm{S} 1) \\
(n=451)\end{array}$ & $\begin{array}{l}\text { Residential zone (S2 }+ \text { S3) } \\
(n=159)\end{array}$ & $\begin{array}{l}\text { Total } \\
(n=610)\end{array}$ \\
\hline D. repens & $22(4.88)$ & - & $22(3.61)$ \\
D. immitis & $1(0.22)$ & $1(0.63)$ & $2(0.33)$ \\
D. repens + D. immitis & $1(0.22)$ & $1(0.63)$ & $2(0.33)$ \\
Total & $24(5.32)$ & $2(1.26)$ & $26(4.26)$ \\
\hline
\end{tabular}

Abbreviations: S1, Devínske Jazero settlement; S2, Danube riverbank; S3, Dog shelter; $n$, number of examined mosquito pools 
Table 3 Occurrence of Dirofilaria spp. in various mosquito species/complexes collected in Bratislava, Slovakia

\begin{tabular}{|c|c|c|c|c|}
\hline \multirow[t]{2}{*}{ Mosquito species/complex } & \multicolumn{4}{|c|}{ Number of positive mosquito pools for Dirofilaria spp. (\%) } \\
\hline & D. repens & D. immitis & D. repens + D. immitis & Total \\
\hline Aedes vexans $(n=138)$ & $9(6.52)$ & - & $1(0.72)$ & $10(7.25)$ \\
\hline Anopheles maculipennis complex $(n=28)$ & $2(7.14)$ & - & - & $2(7.14)$ \\
\hline Anopheles messeae $(n=61)$ & $4(6.56)$ & - & - & $4(6.56)$ \\
\hline Coquillettidia richiardii $(n=26)$ & - & $1(3.85)$ & - & $1(3.85)$ \\
\hline Culex pipiens complex $(n=187)$ & $7(3.74)$ & - & - & $7(3.74)$ \\
\hline Cx. pipiens biotype pipiens $(n=6)$ & - & $1(16.67)$ & - & $1(16.67)$ \\
\hline Ochlerotatus sticticus $(n=41)$ & - & - & $1(2.44)$ & $1(2.44)$ \\
\hline Total $(n=610)$ & $22(3.61)$ & $2(0.33)$ & $2(0.33)$ & $26(4.24)$ \\
\hline
\end{tabular}

Abbreviations: $n$, number of examined mosquito pools

mosquito captures and the community composition in separate trapping areas of Bratislava. According to the number of trapped mosquitoes, it is obvious that the more natural habitat creates better conditions for mosquito biology [7]. The number of mosquitoes collected from the Devínske Jazero sampling site in the urban-fringe zone was more than nine-times higher than that of the residential zone in the city centre.

It is not an unexpected finding that the most abundant species trapped were Ae. vexans and members of the $C x$. pipiens complex. Aedes vexans is a cosmopolitan species, typical for floodplain areas, and the floodplain area of the River Morava on the outskirts of Bratislava seems to be a very suitable environment for this species. Aedes vexans was also found to be the most abundant mosquito species in the Lower Austria Province directly neighbouring the Bratislava region with a large floodplain habitat is very similar to that of Devínske Jazero settlement (sampling site S1 in our study) [32]. The same results with $A$ e vexans being the most frequent species, were also reported from two other surrounding countries: the Czech Republic and Hungary [33, 34].

The next highly abundant mosquito species recorded within the present study belong to the $C x$. pipiens complex. To our knowledge, molecular identification of the Cx. pipiens complex in Slovakia was performed for the first time, and two biotypes were found: the ornithophilic form pipiens, which plays only a minor role as a virus vector, and the medically important anthropophilic and mammophilic form molestus, which is the main vector of West Nile virus (WNV) [2]. The biotype pipiens was more abundant than the biotype molestus in our study. The same results were previously observed in Austria and in Germany, where the molestus biotype were absent in the entire northern and eastern parts of the country $[19,35]$. In our study, the molestus biotype was not detected in the urban-fringe environment, which corresponded with its habitat preferences as a typical urban type [2]. Our preliminary results bring important data, because both biotypes were captured in the same area of an urban environment in this study. The hybridization of these forms was observed in areas of their coexistence, and their hybrids may serve as important bridge vectors of WNV from birds to humans [19]. In a period of frequent WNV outbreaks in several parts of Europe, this finding is greatly disturbing and indicates a risk for human health, especially in urban areas with high density of citizens [36, 37]. The role of dogs as a reservoir of WNV is improbable due to low levels of viremia, but they can serve as sentinels of the infection [38]. In Slovakia, the circulation of WNV in birds was also confirmed recently [39], but extensive research for identifying the real potential of pipiens/molestus hybrid occurrence should be done. Two female specimens of another principal vector of WNV in Europe, $C x$. modestus, were trapped only on the Danube riverbank in the residential zone. The neighbouring Karloveské Rameno river branch, overgrown by reed beds, should be preferred by this species, and its occurrence on the Danube promenade should be expected in the summer months.

Only recently, the first comprehensive study on species distribution within the An. maculipennis complex was performed, and it confirmed An. daciae as a new species in Slovakia [21]. Molecular identification of the maculipennis complex was carried out only at the Devínske Jazero sampling site, in an urban-fringe zone where two species, An. daciae and An. messeae, were caught. In contrast, several years ago, no individuals of An. maculipennis (s.l.) were detected in this locality [40]. The density of both collected species was relatively equal (61 and 56 females, respectively). While An. daciae has been reported for Slovakia only recently, the occurrence of An. messeae was already recognised in 1955, when this species was confirmed as the main vector of malaria in this country [41]. Two other species of the genus Anopheles were found within the present study, $A n$. hyrcanus and An. plumbeus, both with a very low abundance. Anopheles hyrcanus was trapped in the urban- 
fringe zone at Devínske Jazero settlement, in the same area where the species was observed for the first time in Slovakia several years ago $[42,43]$. This species was also confirmed in an adjacent Lower Austria Province and in other neighbouring countries, Hungary and the Czech Republic, where $A n$. hyrcanus was reported quite recently, in 2003 and 2008, respectively [32, 43, 44]. This thermophilic mosquito is widely distributed in the Mediterranean area and represents an invasive species in central Europe. Moreover, today An. hyrcanus is considered an important potential vector for human and avian malaria [45], and at present, when climate change is influencing species distribution, the occurrence of a stable population of An. hyrcanus in the warmest area of Slovakia may represent a serious risk. Anopheles plumbeus was trapped only in the residential zone of Bratislava. Although this mosquito species is predominantly associated with natural grassland and agricultural areas, several studies have pointed to its increasing occurrence in urban environments [46]. Taking into account that An. plumbeus acts as a bridge vector of tropical malaria parasite as well as WNV, the observed inclination towards urban environments might represent an important public health problem in the future $[46,47]$.

Another mosquito species, Cq. richiardii, was also more frequent at the sampling sites located in the residential part of the city. Its anthropophilic behaviour is known even in areas surrounded by fresh waters, in the same conditions as on the Danube riverbank. In neighbouring eastern Austria, Cq. richiardii was the most abundant species, with $31.4 \%$ of the total catch, and was positively associated with slightly elevated Danube water levels and negatively associated with precipitation [32].

Two Ochlerotatus species were identified during this study: three specimens of Och. caspius and the more numerous Och. sticticus predominantly occurred in Devínske Jazero settlement in the urban-fringe zone. Ochlerotatus sticticus was also found to be highly abundant in the Lower Austria Province and showed a strongly positive relation to elevated Danube water levels and excessive periods of sunshine [32].

Molecular analysis of the trapped female mosquitoes for the presence of Dirofilaria DNA revealed the expected dominance of $D$. repens in Slovakia. This finding correlates with the results of the extensive epidemiological study provided by Miterpáková et al. [9], where a majority of dogs in Slovakia were infected with $D$. repens. Regarding D. immitis, using blood-screening methods (Knott test and PCR) only ten dogs with heartworm disease were recorded in Slovakia within the previous ten years (in nine cases a mixed infection with $D$. repens and in one dog only $D$. immitis was confirmed). However, the following serologic survey revealed that $D$. immitis could be expanded more widely concerning occult infections in certain endemic areas [48]. This hypothesis is also supported herein by the presented results, as $D$. immitis has been detected in mosquitoes trapped in both studied habitats.

Only one study regarding mosquito investigation for dirofilarial DNA presence has thus far been carried out in Slovakia [12]. This research based in the Košice region, in the eastern part of Slovakia, confirmed Ae. vexans as a vector for both $D$. repens and $D$. immitis. However, a large variety of mosquito species can serve as vectors for Dirofilaria spp. [2]. In the presented study, five different species (Ae. vexans, An. messeae, Cq. richiardii, Cx. pipiens biotype pipiens and Och. sticticus) and a few unidentified members from the $C x$. pipiens and Anopheles maculipennis complexes were confirmed as potential vectors of Dirofilaria spp. in Slovakia. The majority of positive pools was detected among the Ae. vexans and the $C x$. pipiens complex, two of the most abundant mosquito taxa collected in this study. Aedes vexans, the floodplain mosquito species, is abundant in the summer months, in the period when the peak activity of microfilaria fluctuation was identified in dogs from Slovakia $[2,9]$. This most abundant and one of the frequently infected species in Europe (Italy, Germany, the Czech Republic, Hungary, Serbia, Romania) plays a key role in the spread of Dirofilaria spp. [34, 49-53].

Due to late establishment of the new molecular differentiation of cryptic groups, only limited data are available on filarioid occurrence in these mosquitoes. In our study, only $A n$. messeae was found to be positive for $D$. repens, while a study in Germany by Kronefeld et al. [50] confirmed $D$. repens only in An. daciae. To the best of our knowledge, these are the only two screenings for Dirofilaria parasites among species identified within the An. maculipennis group in Europe.

Two mosquito taxa were found to be positive solely for D. immitis in our study. Surprisingly, the heartworm DNA was detected in the ornithophilic form $C x$. pipiens biotype pipiens which prefers birds as blood hosts. Recently, the same results were obtained in Spain, where $D$. immitis was found in the head and thorax of the pipiens biotype. Accordingly, it could be suggested that the $C x$. pipiens biotype pipiens might be a competent vector for canine heartworm transmission [54] and these findings may bring a new insight into the understanding of the low prevalence of $D$. immitis infection in Slovakia. It is likely that this occasionally anthropophilic and mammophilic feeder is not able to infect a high number of carnivore hosts. On the other hand, $D$. immitis solitary or together with $D$. repens, was also detected in pools of animal- and humanfeeding mosquito species: Ae. vexans, Och. sticticus and Cq. richiardi. Although mosquito field studies are not able to specify the effectiveness of parasite transmission, it is clear that some unidentified differences exist in D. immitis-vector specificity [55]. Several previous studies have declared genetic and morphological differences responsible 
for the susceptibility or resistance of various mosquito species to Dirofilaria parasites [56, 57], but little is known about interactions between both dirofilarial species when they coincide in the same mosquito host [6]. In our study, only two mosquito species (Ae. vexans and Och. sticticus) hosted both Dirofilaria spp.

The relative prevalence of dirofilariosis detected in our study was shown to be higher than in neighbouring Austria, the Czech Republic and Poland. Furthermore, only $D$. repens was found in mosquitoes from these countries $[50,58,59]$. On the other hand, in mosquitoes from Hungary, $D$. immitis was also confirmed, and the relative prevalence of $D$. repens was higher when compared to Slovakia [34].

It has been suggested that a high density of suitable definitive hosts should be related with higher abundance of dirofilariosis [60]. However, the majority of Dirofilaria-positive mosquito pools came from the Devínske Jazero settlement, the more natural, less urbanised area of Bratislava. Although mosquito species richness quantified by Menhinick's diversity index was higher in the residential zone, the garden zone in Devínske Jazero and an adjacent floodplain area of the River Morava create proper conditions for mosquito and Dirofilaria development. This is evidenced by large number of captured mosquitoes, relatively high species richness and also by their high positivity for Dirofilaria spp.

On the contrary, in the city centre, dirofilarial DNA was identified in only $1.26 \%$ of analysed mosquito pools. Moreover, the number of trapped mosquitoes was much lower despite the use of the same sampling method. On the other hand, monoinfection with $D$. immitis was detected only in the urban habitat. In addition, in recent years extensive floods followed by mosquito outbreaks have frequently occurred directly in the city centre of Bratislava, which creates a potential risk for increasing the abundance of dirofilariosis not only in dogs but also in humans.

\section{Conclusions}

This study brings important data concerning mosquito species abundance and composition in urban area of Bratislava, Slovak capital city. In addition, primary molecular analyses within the $C x$. pipiens complex in Slovakia were performed, and the co-occurrence of two biotypes were identified in the same environment: the $C x$. pipiens biotype pipiens and the $C x$. pipiens biotype molestus. Further investigation of mosquito material revealed $4.26 \%$ relative prevalence of Dirofilaria spp., whereby both species, $D$. repens and $D$. immitis, were identified. Dirofilaria spp. were detected for the first time in Slovakia in mosquitoes other than Ae. vexans, i.e. D. repens in Anopheles messeae and unidentified members of An. maculipennis and Cx. pipiens complexes, and D. immitis in Coquillettidia richiardii and Cx. pipiens biotype pipiens. Both dirofilarial species in were confirmed in Och. sticticus. The more natural habitat of the urbanfringe zone creates appropriate conditions for mosquito biology. Also, most of the positive pools came from this area, though the occurrence of potential definitive hosts was more abundant in the urban zone. Accordingly, the suitable conditions for vectors' survival would represent the main risk factor for dirofilariosis transmission.

\section{Abbreviations}

PCR: Polymerase chain reaction; DNA: Deoxyribonucleic acid; cox1: Cytochrome c oxidase subunit 1; IBA: Important Bird Area; ace2: Acetylcholinesterase-2 gene; CQ11: Microsatellite of the locus CQ11; ITS2: Internal transcribed spacer 2; rRNA: Ribosomal ribonucleic acid; PBS: Phosphate-buffered saline; nad4 gene: Reduced nicotinamide adenine dinucleotide of the dehydrogenase subunit 4; BLAST: Basic Local Alignment Search Tool

\section{Acknowledgements}

The authors are grateful to the European Network for Neglected Vectors and Vector-Borne Infections (EurNegVec) COST Action (WG5), Dr Hans-Peter Fuehrer, Dr Carina Zittra and their team (VETMEDUNI, Vienna), for the opportunity to acquire new skills in molecular identification of the Culex pipiens complex. The authors would like to thank Dr Oldřich Šebesta for his help with mosquito identification, the employees of dog shelter Sloboda Zvierat and the Botanical Garden of Comenius University for their assistance with mosquito trapping. We are also thankful to Dr Aleksander Masny, National Institute of Public Health - National Institute of Hygiene, Warsaw, Poland, for providing Setaria control DNA. Last but not least, the authors are grateful to Mr David McLean for proofreading the manuscript.

\section{Funding}

The study was supported by the Scientific Grant Agency VEGA project No. 2/ 0018/16, Slovak Research and Development Agency, project APW-15-0114, and by the project "Centre of Excellence for Parasitology" (code ITMS: 26220120022), supported by the Research and Development Operational Programme funded by the ERDF (0.5).

\section{Availability of data and materials}

All relevant data are included within the article. Nucleotide sequences of $D$. repens and D. immitis cox 1 gene fragment were deposited in the GenBank database under the accession numbers MG787424 and MG787425, respectively.

\section{Authors' contributions}

VČ and MM were responsible for writing the manuscript. VČ provided morphological and molecular mosquito identification and was responsible for mosquito screening for filarioid helminths using molecular approaches. $\mathrm{HB}$ and IR contributed highly to the molecular identification of mosquito specimens from Anopheles maculipennis. DV, ES, MDz and ZH performed mosquito sampling and sample preparation. MM was responsible for the study design and the project coordination and supervision. All authors read and approved the final manuscript.

Ethics approval and consent to participate

Not applicable.

\section{Competing interests}

The authors declare that they have no competing interests.

\section{Publisher's Note}

Springer Nature remains neutral with regard to jurisdictional claims in published maps and institutional affiliations.

\section{Author details}

${ }^{1}$ Institute of Parasitology, Slovak Academy of Sciences, Hlinkova 3, 04001 Košice, Slovakia. ${ }^{2}$ State Veterinary and Food Institute, Botanická 15, 84252 Bratislava, Slovakia. ${ }^{3}$ Institute of Vertebrate Biology, v.v.i, Czech Academy of Sciences, Květná 8, 60365 Brno, Czech Republic. ${ }^{4}$ Department of Zoology, Faculty of Natural Sciences, Comenius University, Mlynská dolina B-1, SK-842 15 Bratislava, Slovakia. 


\section{Received: 14 February 2018 Accepted: 11 April 2018 Published online: 24 April 2018}

\section{References}

1. Medlock JM, Hansford KM, Schaffner F, Versteirt V, Hendrickx G, Zeller H, Van Bortel W. A review of the invasive mosquitoes in Europe: ecology, public health risks, and control options. Vector Borne Zoonotic Dis. 2012;12:435-47.

2. Becker N, Petric D, Zgomba M, Boase C, Madon M, Dahl C, Kaiser A. Mosquitoes and their control. 2nd ed. Berlin: Springer; 2010.

3. Mahakalkar AL, Sapkal HP, Baig MM. Report of high genetic diversity of filarial worm, Wuchereria bancrofti from endemic region of eastern Maharashtra (India). Helminthologia. 2017;54:292-7.

4. Pampiglione S, Rivasi F. Human dirofilariasis to Dirofilaria (Nochtiella) repens: an update of world literature from 1995-2000. In: Genchi C, Rinaldi L, Cringoli G, editors. Dirofilaria immitis and D. repens in dog and cat and human infections. Naples: Rolando Editore; 2007. p. 83-116.

5. Eldridge BF, Edman JD. Medical entomology. Dordrecht: Springer; 2000.

6. Simón F, Gonzáles-Miguel J, Diosdado A, Gómez PJ, Morchón R, Kartashev $V$. The complexity of zoonotic filariasis episystem and its consequences: a multidisciplinary view. Biomed Res Int. 2017;2017:6436130.

7. Ferraguti M, Martínez-de la Puente J, Roiz D, Ruiz S, Soriguer R, Figuerola J. Effects of landscape anthropization on mosquito community composition and abundance. Sci Rep. 2016;6:29002.

8. Miterpáková M, Antolová D, Hurníková Z, Dubinský P. Dirofilariosis in Slovakia a new endemic area in central Europe. Helminthologia. 2008;4:20-3.

9. Miterpáková M, Iglódyová A, Čabanová V, Stloukal E, Miklisová D. Canine dirofilariosis endemic in Central Europe - 10 years of epidemiological study in Slovakia. Parasitol Res. 2016;11:2389-95.

10. Miterpáková M, Antolová D, Ondriska F, Gál V. Human Dirofilaria repens infections diagnosed in Slovakia in the last 10 years (2007-2017). Wien Klin Wochenschr. 2017;12:634-41.

11. Bocková E, Kočišová A, Letková V. First record of Aedes albopictus in Slovakia. Acta Parasitol. 2013;58:603-6.

12. Bocková E, Iglódyová A, Kočišová A. Potential mosquito (Diptera: Culicidae) vector of Dirofilaria repens and Dirofilaria immitis in urban areas of eastern Slovakia. Parasitol Res. 2015;114:4487-92.

13. Reháčková T, Lehotská $B$, Nevřelová M, Pauditšová E, Ružičková J. Forest fragments in built-up territory of Bratislava. Bratislava: Cicero; 2007. (In Slovak).

14. Šeffer J, Stanová V. Morava River floodplain meadows - importance, restoration and management. Bratislava: DAPHNE-Centre for Applied Ecology; 1999 .

15. Natura 2000. State Nature Conservancy of the Slovak Republic. 2000. http:// natura2000.eea.europa.eu/Natura2000/SDF.aspx?site=SKUEV0313. Accessed 23 Jan 2018.

16. Bohuš M, Ružičková J, Lehotská B. Danube river, its ecosystems and human activity. Bratislava: Univerzita Komenského v Bratislave; 2011. (In Slovak).

17. Kumar NP, Rajavel AR, Natarajan R, Jambulingam P. DNA barcodes can distinguish species of Indian mosquitoes (Diptera: Culicidae). J Med Entomol. 2007:44:1-7.

18. Smith J, Fonseca DM. Rapid assays for identification of members of the Culex (Culex) pipiens complex, their hybrids, and other sibling species (Diptera: Culicidae). Am J Trop Med Hyg. 2004;70:339-45.

19. Zittra C, Flechl E, Kothmayer M, Vitecek S, Rossiter H, Zechmeister T, Fuehrer HP. Ecological characterization and molecular differentiation of Culex pipiens complex taxa and Culex torrentium in eastern Austria. Parasit Vectors. 2016;9:197.

20. Bahnck C, Fonseca DM. Rapid assay to identify the two genetic forms of Culex (Culex) pipiens L. (Diptera: Culicidae) and hybrid populations. Am J Trop Med Hyg. 2006;75:251-5.

21. Blažejová H, Šebesta O, Rettich F, Mendel J, Čabanová V, Miterpáková M, et al. Cryptic species Anopheles daciae (Diptera: Culicidae) found in the Czech Republic and Slovakia. Parasitol Res. 2018;117:315-21.

22. Kronefeld $\mathrm{M}$, Werner $\mathrm{D}$, Kampen $\mathrm{H}$. Molecular confirmation of the occurrence in Germany of Anopheles daciae (Diptera, Culicidae). Parasit Vectors. 2014;5:250.

23. Casiraghi M, Anderson TJC, Bandi C, Bazzocchi C, Genchi CA. phylogenetic analysis of filarial nematodes: comparison with the phylogeny of Wolbachia endosymbiont. Parasitology. 2001;122:93-103.

24. Rishniw M, Barr SC, Simpson KW, Frongillo M, Franz M, Dominquez AJL. Discrimination between six species of canine microfilariae by a single polymerase chain reaction. Vet Parasitol. 2006;135:303-14.
25. Laaksonen S, Kuusela J, Nikander S, Nylund M, Oksanen A. Outbreak of parasitic peritonitis in reindeer in Finland. Vet Rec. 2007;160:835-41.

26. Simón F, Siles-Lucas M, Morchón R, González-Miquel J, Mellado I, Carretón E, Montoya-Alonso JA. Human and animal dirofilariasis: the emergence of a zoonotic mosaic. Clin Microbiol Rev. 2012;25:507-44.

27. Tomasello D, Schlagenhauf P. Chikungunya and dengue autochtonmous cases in Europe, 2007-2012. Travel Med Infect Dis. 2013;11:274-84.

28. Badieritakis E, Papachristos D, Larinpoulos D, Stefopoulou A, Kolimenakis A, Bithas K, et al. Aedes albopictus (Skuse, 1895) (Diptera: Culicidae) in Greece: 13 years of living with the Asian tiger mosquito. Parasitol Res. 2018;117:453-60.

29. Kwon YS, Bae MJ, Chung N, Lee YR, Hwang S, Kim SA, et al. Modelling occurrence of urban mosquitos based on land use types and meteorological factors in Korea. Int J Environ Res Publ Health. 2015;12:13131-47.

30. Fitz O. Mosquito calamities caused by flooding activity - report. Regional Public Health Authority Bratislava. 2013:2. (In Slovak). http://www.archiv. karlovaves.sk/sites/default/files/OZNAMENIE_Regionalny_urad_verejneho_ zdravotnictva.pdf. 23 Jan 2018.

31. Tomšík K. Summary report of the flooding activity, its consequences and prevention. Magistrát hlavného mesta Slovenskej Republiky Bratislavy, Bratislava. 2013;44. (In Slovak). http://www.bratislava.sk/MsZ/Archiv/MsZ_13_ 09_25_26/MsZ_body_25_260913_anonym/49_Povodne_sprava.pdf. 23 Jan 2018.

32. Zittra C, Vitecek S, Obwaller AG, Rossiter H, Eigner B, Zechmeister T, et al. Landscape structure affects distribution of potential disease vectors (Diptera: Culicidae). Parasit Vectors. 2017;10:205.

33. Rudolf I, Šebesta O, Mendel J, Betášová L, Bocková E, Jedličková P, et al. Zoonotic Dirofilaria repens (Nematoda: Filarioidea) in Aedes vexans mosquitoes, Czech Republic. Parasitol Res. 2014;13:4663-7.

34. Kemenesi G, Kurucz K, Kepner A, Dallos B, Oldel M, Herczeg R, et al. Circulation of Dirofilaria repens, Setaria tundra, and Onchocercidae species in Hungary during the period 2011-2013. Vet Parasitol. 2015;214:108-13.

35. Rudolf M, Czajka C, Börstker J, Melaun C, Jöst H, von Thein H, et al. First nationwide surveillance of Culex pipiens complex and Culex torrentium mosquitoes demonstrated the presence of Culex pipiens biotype pipiens/ molestus hybrids in Germany. PLoS One. 2013:8:71832.

36. Sambri V, Capobianchi M, Charrel R, Fyodorova M, Gaibani P, Gould E, et al. West Nile virus in Europe: emergence, epidemiology, diagnosis, treatment, and prevention. Clin Microbiol Infect. 2013;19:699-704.

37. Fonseca DM, Keyghobadi N, Malcolm CA, Mehmet C, Schaffner F, Mogi M, et al. Emerging vectors in the Culex pipiens complex. Science. 2004;303:1535-8.

38. Ratovonjato J, Rajerison M, Rahelinirina S, Boyer S. Serologic surveillance for West Nile Virus in Dogs, Africa. Emerg Infect Dis. 2014;20:1415-7.

39. Csank T, Bhide K, Bencúrová E, Dolinská S, Dzewnioková P, Major P, et al. Detection of West Nile virus and tick-borne encephalitis virus in birds in Slovakia, using a universal primer set. Arch Virol. 2016;161:1679-83.

40. Strelková L, Halgoš J. Mosquitoes (Diptera, Culicidae) of the Morava River floodplain, Slovakia. Cent Eur J Biol. 2012;7:917-26.

41. Okáli I, Labuda M. History of malaria in Slovakia. Entomol Probl. 1988;18: 233-51. (In Slovak)

42. Halgoš J, Benková I. First record of Anopheles hyrcanus (Diptera: Culicidae) from Slovakia. Biológia. 2004;59:68.

43. Šebesta O, Rettich F, Minár J, Halouzka J, Hubálek Z, Juřicová Z, et al. Presence of the mosquito Anopheles hyrcanus in South Morava, Czech Republic. Med Vet Entomol. 2009;23:284-6.

44. Tóth S. Mosquito fauna (Diptera: Culicidae) of Sopron and its environs. Fol Hist Nat Mus Matr. 2003;27:327-32. (In Hungarian).

45. Seidel B, Silbermayr K, Kolodziejek J, Indra A, Nowotny N, Allerberger F. Detection of Plasmodium sp.-infested Anopheles hyrcanus (Pallas, 1771) (Diptera: Culicidae) in Austria, 2012. Wien Klin Wochenschr. 2013;125:139-43.

46. Townroe S, Callaghan A. British container breeding mosquitoes: the impact of urbanisation and climate change on community composition and phenology. PLoS One. 2014;9:95325.

47. Schaffner F, Thiéry I, Kaufmann C, Zettor A, Lengeler C, Mathis A, Bourgouin C. Anopheles plumbeus (Diptera: Culicidae) in Europe: a mere nuisance mosquito or potential malaria vector? Malaria J. 2012;11:393.

48. Čabanová V, Pantchev N, Hurníková Z, Miterpáková M. Recent study on canine vector-borne zoonoses in southern Slovakia - serologic survey. Acta Parasitol. 2015;60:749-58.

49. Latrofa MS, Montarsi F, Ciochetta S, Annoscia G, Dantas-Torres F, Ravagan S, et al. Molecular xenomonitoring of Dirofilaria immitis and Dirofilaria repens 
in mosquitoes from north-eastern Italy by real-time PCR coupled with melting curve analysis. Parasit Vectors. 2012;5:76.

50. Kronefeld M, Kampen H, Sassnau R, Werner D. Molecular detection of Dirofilaria repens and Setaria tundra in mosquitoes from Germany. Parasit Vectors. 2014;7:30

51. Rudolf I, Bakonyi T, Šebesta O, Mendel J, Peško J, Betášová L, et al. West Nile virus lineage 2 isolated from Culex modestus mosquitoes in the Czech Republic, 2013: expansion of the European WNV endemic area to the North? Euro Surveill. 2014;19:20867.

52. Kurucz K, Kepner A, Krtinic B, Zana B, Földes F, Bányai K, et al. First molecular identification of Dirofilaria spp. (Ochocercidae) in mosquitoes from Serbia. Parasitol Res. 2016;115:3257-60.

53. Ionică AM, Zittra C, Wimmer V, Leitner N, Votýpka J, Modrý D, et al. Mosquitoes in the Danube Delta: searching for vectors of filarioid helminths and avian malaria. Parasit Vectors. 2017:10:324.

54. Bravo-Barriga D, Parreira R, Almeida PG, Calado M, Blanco-Ciudad J, SerranoAguilera FJ, et al. Culex pipiens as a potential vector for transmission of Dirofilaria immitis and other unclassified Filarioidea in Southwest Spain. Vet Parasitol. 2016;15:173-80.

55. Morchón R, Carretón E, Gonzáles-Miquel J, Mellado-Hernández I. Heartworm disease (Dirofilaria immitis) and their vectors in Europe - new distribution trends. Front Physiol. 2012;3:196.

56. Cancrini G, Gabrielli S. Vectors of Dirofilaria nematodes: biology, behaviour and host/parasite relationships. In: Genchi C, Rinaldi L, Cringoli G, editors. Dirofilaria immitis and $D$. repens in dog and cat and human infections. Naples: Rolando Editore; 2007.

57. Morchón R, Bargues MD, Latorre JM, Melero-Alcíbar R, Pou-Barreto C, MasComa S, Simón F. Haplotype H1 of Culex pipiens implicated as natural vector of Dirofilaria immitis in an endemic area of western Spain. Vector Borne Zoonotic Dis. 2007;7:653-8.

58. Silbermayr K, Eigner B, Joachim A, Duscher GG, Seidel B, Allerberger F, et al. Autochtonous Dirofilaria repens in Austria. Parasit Vectors. 2014;7:226.

59. Masny A, Salamatin R, Rozej-Bielicka W, Golab E. Is molecular xenomonitoring of mosquitoes for Dirofilaria repens suitable for dirofilariosis surveillance in endemic region? Parasitol Res. 2016;115:511-25.

60. Trájer A, Rengei A, Farkas-Iványi K, Bede. Fazekas Á. Impacts of urbanisation level and distance from potential natural mosquito breeding habitats on the abundance of canine dirofilariosis. Acta Vet Hung. 2016;64:340-59.

\section{Ready to submit your research? Choose BMC and benefit from:}

- fast, convenient online submission

- thorough peer review by experienced researchers in your field

- rapid publication on acceptance

- support for research data, including large and complex data types

- gold Open Access which fosters wider collaboration and increased citations

- maximum visibility for your research: over $100 \mathrm{M}$ website views per year

At BMC, research is always in progress.

Learn more biomedcentral.com/submissions 